\title{
POWERFUL KNOWLEDGE AS THE FUTURE OF SCHOOL CURRICULUM
}

\author{
Gunita Elksne \\ University of Latvia, Latvia
}

\begin{abstract}
The global, social, economic and technological conditions of the 21st century are drastically changing the way societies and education policymakers understand the goals of education. Pedagogy has always been about how to pass on the knowledge, skills, values, and development of one's personality to the next generation, to create the conditions for growth that meet everyone's needs and provide equal opportunities. However, today this issue has become more relevant than ever as the world is changing very rapidly, society, its values, and needs are changing, as confirmed by the UNESCO goals for 2030.

Young, pointing out that in many countries education policy neglects what knowledge a student needs today, creates a theory of "Powerful knowledge" based on the work of educational sociology authors such as Durkheim, Bernstein, Bourdieu. The goal of this paper is to conduct a literature review of the concept of 'powerful knowledge'.

Since the year 2009, this term has been described in many articles but is still in development. Analyzing the works of Young and Muller, as well as getting to know works of other authors who complement and develop the concept (Wheelahan, Lambert, Deng, etc.) and those who are more skeptical (White), the definition and features of Powerful Knowledge have been revealed and scientists' thoughts on what makes knowledge "powerful", why it is needed, what place it can play in school curricula have been collected, as well as highlighting questions that have not yet been answered clearly.
\end{abstract}

Keywords: curriculum, powerful knowledge, sociology of education.

\section{Introduction}

21st century has put as in a situation, where the role of science and technologies is rapidly growing in society as a whole and also in each individual's personal growth, situation, where new areas and directions to human activity are emerging, where you must have modern knowledge to succeed, but areas in which you need basic, routine skills are disappearing. Consequently, there are pressing questions about the current goals, tasks, and opportunities for education, schools, curricula, and teachers. Education reforms are underway in many countries to respond to the rapid change, seeking to answer questions about the role of schools and teachers nowadays, what a modern student is, how and what to teach them. Educational organizations also pay particular attention to the importance of this issue. The Center for Curriculum Redesign (CCR) explores curriculum 
opportunities to reach the present world and be prepared for a future characterized as volatile, uncertain, complex, ambiguous - VUCA. The center offers an education system focused on knowledge, skills, character, and meta-learning, calling it four-dimensional education (Fadel, Bialik, \& Trilling, 2015). UNESCO creates the International Commission for the Futures of Education, which will produce a report by November 2021 analyzing the role of education in the world, taking into account global trends such as geopolitical unrest, environmental degradation, and climate change, changing patterns of human mobility and the exponential pace of scientific and technological innovations. The impact of future social, economic, technological and environmental challenges on education will be assessed and recommendations for action taken at different policy levels (UNESCO, 2019). However, it is already quite clear that school and teachers are not the only providers of information to the pupil, as a result, the role of schools as a conveyor of information from one generation to another, which has been a common practice for centuries, is no longer productive and relevant. The skills and competences necessary for a quality life in the 21st century are often talked about in the educational space. The labor market basically declares what skills and competencies workers need without mentioning knowledge, sometimes considering education policy only as of the basis for a successful economy, so Young believes that the economy will never support knowledge-based school programs (Young, Lambert, Roberts, \& Roberts, 2014). The European Union Recommendation on Key Competences for Lifelong Learning - A European Reference Framework published on 18 December 2006 identifies 8 key competencies (EU, Council Recommendation on Key Competences for Lifelong Learning, 2019), including several theories on competences. The authors try to classify competences and look for key competences. It also looks for metacompetencies that let you know what a person knows (Weinert, 2001). Knowledge-skills-attitudes are one of the most common basic formulas for competences, and experience-based learning is often emphasized as a starting point for competence acquisition. As well as the Rome Declaration, adopted by the leaders of the 27 Member States and the European Council, the European Parliament and the leaders of European Commission on March 25, 2017, pledges to create a "Union where young people get the best education and training and can study and find work across the continent” (EU, The Rome Declaration, 2017). Admittedly, many education researchers believe that "With a good education, today's students in the future should become job creators rather than job seekers on the labor market (Oganisjana, 2012). Many documents also noted the importance of modern knowledge, but there is a lack of conviction that everyone understands what is meant by "knowledge" in the same way. Educational sociologists raise the question of what knowledge is available to a pupil at school and who has the right to decide it. In this context, the term "Powerful Knowledge" 
appears in 2007 and is being developed and promoted since 2009 by a professor of education Michael Young, emeritus professor of education Johan Muller. Since this term and its concept is fairly young, the problem is that it is not yet clearly defined. The goal of this paper is to conduct a literature review of the concept of 'powerful knowledge', so to be able to do this, the most important works by the Young and Muller about this concept over the last 10 years, as well as the views of opponents, were analyzed.

\section{The basics of the Powerful Knowledge concept}

The foundation of the concept of powerful knowledge (PK) goes back to the sociology of education when trying to answer questions like - what is knowledge and who has the right to have it, how we understand the relationship between knowledge and society.

First, the concept originates in the views of Emile Durkheim, a French sociologist, and pioneer of educational sociology, who says that knowledge is social - knowledge is rooted in reality and reality is social - knowledge is needed to understand the world to change it. Durkheim believes that we perceive the world differentiated by our thoughts and experiences, we differentiate knowledge according to how we see the reality of the world and intuitively feel that some knowledge is "better" than others - epistemic, morally, and ethically. Durkheim's works also provide a starting point for the separation of knowledge and experience as well as between theoretical and everyday knowledge. Durkheim's conclusion, which is also at the core of the PK concept, is that the progress of humanity is closely linked to specialized knowledge in the field (Durkheim, 1956). However, Young points out that not all specialized knowledge is powerful in the context of the concept he and his companion developed.

The concept of PK is also based on the idea of the British sociologist, a representative of the critical direction of education sociology and linguist Basil Bernstein on the different possibilities of different forms of knowledge, the cultural code and hierarchical knowledge structures he has developed. Bernstein examines the reproductive meaning of education - it adds value to certain knowledge and limits the field of who can determine which knowledge will be acquired. He also sees teachers and schools as power holders (Bernstein, 2000). Based on Bernstein's conclusions on knowledge differentiation, the authors of the PK concept distinguish between two boundaries: 1. Between subjects in school, and 2. between everyday knowledge and what is acquirable at school.

Young and Muller also refer to Vygotsky's notion of specialization or the differentiation of knowledge from experience that arose from the theory of human development. Vygotsky believed that the purpose of school curricula was to provide students with the opportunity to acquire theoretical knowledge in every 
subject. Distinguishing theoretical knowledge from the pupils' previous life experiences was one of the central issues for Vygotsky, as was Durkheim (Young \& Muller, 2016, p. 121). The authors also based their theory on the field theory of French sociologist Pierre Bordieu (each field has its types of capital), and one of the capital is a cultural capital with education in the center (Bordieu, 1997). The idea of the conventionality of capital theory has been used in analyzing the situation in the education system and the opportunities for improving quality.

Although the concept has old roots, the authors use a socio-epistemic view of knowledge, but it is a whole new way of thinking about it. The PK emphasizes the objective nature of knowledge, a value-free reality (Young \& Muller, 2016, p. 116). Although it is precisely the lack of objectivity in the knowledge that researchers sometimes consider their weak spot. "All knowledge is situated knowledge, reflecting the position of the producer or knower, at a certain historical moment in given cultural context” (Lennon, 2010), (Alderson, 2019) The concept of powerful knowledge has been developed both as a sociological concept and as a curriculum principle and is being used by a growing cohort of researchers.

It first appears in Wheelahan's work (Wheelahan, 2007). The concept has gained interest among scholars as well as school leaders and other educational staff. EBSCO's Database on 27/01/2020 contains 503 articles on the keyword "powerful knowledge". Swedish scientists believe that PK should be developed as an analytical concept (Gericke, Hudson, Olin-Scheller, \& Stolare, 2018). However, there are also critics who ask questions and doubts the usefulness of the PK- "what is it that puts the power in powerful knowledge? Why call the knowledge associated with specialist academic groups 'powerful'?" and points out that not everyone who uses the concept of PK has a common understanding of it, believes that the characterization of PK is entirely consistent with the existing term specialized knowledge, although it does not deny the positive aura and attractiveness of the concept (White, 2019). The concept of "Powerful knowledge" is based on two ideas: each field of science has the "best, most valuable" knowledge, and all decisions on knowledge in school curricula are based on differentiation that there are different types of knowledge (Young M., 2014)

Powerful knowledge as a curriculum principle. Authors of Powerful Knowledge Young, Muller, Lambert (Lambert, 2018), offer curriculum frameworks that prioritize knowledge in individual subjects. The PK starts with the idea of equal citizens with equal rights to knowledge; rights that should not be restricted by thinking abilities or motivation, ethnicity, class or gender. The curriculum should be considered as guaranteed equality based on the best knowledge or at least a gradual approach to its acquisition (Playfair, 2015). The authors emphasize the directions that can be found based on PK theory and school 
programs: 1) power and knowledge in social theory, 2) power, knowledge and curriculum theory (Muller \& Young, 2019), (White, 2019).

Power and knowledge in social theory. These concepts have been studied extensively individually, but their interconnection has led to a widespread debate among sociologists, psychologists, philosophers, and educators. Powerful knowledge is powerful because it provides the best insight into the natural and social world we have and helps us transcend our individual experiences (Young M., 2013), (Young \& Muller, 2013). There is a lot of discussion and authors' explanations about the difference between "Powerful knowledge" and "knowledge of the power" (Muller \& Young, 2019). The difference - knowledge as a superiority tool and knowledge that has power itself. The PK does not show power over students but gives power to them. It gives them a chance to think for themselves and do. PK is potentially available to all who acquire it, fundamentally democracy and social justice (Muller \& Young, 2019, p. 3). This knowledge is not elitist. The comprehension of power in this concept linked to Potentia vs. Potestas. Mcfahn describes powerful knowledge as "right" and "unchallengeable”, “pretty handy”, “emancipatory” (Mcfahn, 2019).

Power, knowledge and curriculum theory. Young, thinking about the role of social differentiation in knowledge and the boundaries of knowledge, outlines three future scenarios for school programs:

1. Future - knowledge is a set of fixed, verifiable concepts, nonnegotiable, an extension of the past.

2. Future - Recognizes that knowledge has social and historical roots, and the special needs of society are important. Interdisciplinary knowledge is becoming topical, subject boundaries are converging, and education is based on the student experience.

3. Future - Believes knowledge is created by specialists of the field, who continue to develop knowledge, therefore knowledge is faulty, debatable, variable. Believes that segregated subjects are the best way to give students access to 'powerful knowledge' which is a set of subject-based insights and pedagogical techniques that work together to allow all students access to the curriculum in a way that allows them to participate in meaningful learning (Young, Lambert, Roberts, \& Roberts, 2014), (Lambert, 2013).

Young believes that PK should be the backbone of formal education, that it is time to restore the importance of knowledge, a central role in education (Young M., 2014). In his view, PK has independent content, free from the knowledge that students gain from their daily experiences, from the context in which they live in, they are academic, specialized in both acquisition and transmission, not every day. Young also distinguishes between knowledge and pedagogy. School curricula must have the knowledge to which everyone has the 
same rights and opportunities, but the experience of pupils is related to pedagogy, how the teacher engages pupils and makes the program accessible. The point of the PK is to confirm that social interests do not replace what is important in terms of education (Muller \& Young, 2019). Deng (Deng, 2015), disagrees, believing that we cannot leave didactics unexamined- how knowledge is selected and transformed into curriculum content, what educational potential content has, and how such potential can be disclosed or unlocked for the development.

5 types of PK (Maude, 2015): 1. Knowledge that provides students with 'new ways of thinking about the world 2. Knowledge that provides students with powerful ways of analyzing, explaining and understanding. 3. Knowledge that gives students some power over their knowledge. 4. Knowledge that enables young people to follow and participate in debates on significant local, national and global issues 5 . Knowledge of the world.

Powerful knowledge is not distributed unequally (Young \& Muller, 2016, p. 117). This is a question of the place for different subjects in school curricula. At the moment, they place significant emphasis on STEM subjects. These subjects provide greater opportunities for transforming, anticipating, and managing the material world, but are they the only ones? The balance has been in favor of STEM since the Science Revolution of the 18th century.

Scientists also discuss with Young and Muller the goals and objectives of schools, putting knowledge in opposition to well-being and happiness, believing that well-being and high-quality knowledge are two separate things (Cigman, 2012). Others, such as (White, 2018), are reluctant to agree that PK is placed at the center of school curricula, believing that practices and other forms of knowledge should not be overlooked. As there is as yet no clear and unambiguous definition of $\mathrm{PK}$, the range of unanswered questions is still quite wide, but at the same time, they also help the concept to develop.

Powerful knowledge attributes. Young (Young, 2009), describes powerful knowledge as:

1. Distinct from common sense knowledge

2. Systematic

3. Specialized

This means that powerful knowledge can serve as a basis for generalization and thinking outside specific contexts or cases.

As mentioned above, PK is separated from everyday knowledge, teachers help pupils to take steps from their current cognition towards very specific ideas (Alderson, 2019).

PK is the result of systematic research, within well-defined disciplines with a well-defined focus, concepts that are interconnected, generalizable, and subdivided into subjects. 
PK as a specialized knowledge is socio-epistemic formation. Mostly created in universities. The question of how to recontextualize the 'best' knowledge created in universities and offer it to school subjects is a pressing issue.

The author of the concept selects three PK attributes (Muller \& Young, 2019):

1. Academic knowledge contains creativity, the possibility to expand with other contexts, if there is such knowledge, then there is potential to create something new, there are unpredictable opportunities

2. School subjects deepen students' understanding of the formation of knowledge in the relevant field of science. The courses must first give an idea of the structure of the subject before the admirers of the subject can generate new ideas.

3. Ability to generate new ideas, teachers need to know their subject well, be good leaders if the teachers are successful then the students will: be confident in the quality of judgment and understanding, their material and conceptual capabilities in the subject, aware that they have learned only a fracture, but now are able to make new connections, gain new information, generate new ideas.

White (White, 2019), sees them as one attribute - the ability to generate new ideas - presented in three different contexts. Also, White also adds that the ability to generate new ideas is not always $\mathrm{PK}$, it is also possible to produce completely destructive ideas/thoughts.

Although not everything is clear in the context of PC - definitions, and terms, their content is in the process of being developed and shared -, and the debates among scientists continues, but it is clear that the return to the importance of knowledge has begun, likely to be called "powerful knowledge".

\section{Conclusions}

1. The concept of Powerful Knowledge was developed by Young and Muller as an opportunity for school programs to create socially equal education from 2009 onwards.

2. Powerful knowledge is a socio-epistemic concept.

3. PK theory`s roots can be found in the works of Durkheim, Bernstein, Vygotsky.

4. In the context of Curriculum theory, the questions of the meaning of "power" in the context of the PK and the place of PK in the curriculum are being considered.

5. In Young`s views, there are three different scenarios for the existence of the school curriculum, with PK being the main one in the third scenario.

6. Important attributes of PK are systematic, specialization. 
7. The concept of PK is still in development and there are many uncertainties to which other scientists point out.

8. The PK has gained recognition and popularity amongst both scientists and educational staff.

\section{References}

Alderson, P. (2019, August). Powerful kno Muller \& Young, 2019wledge and the curriculum; contradictions and dichotomies. British Educational Research Journal, 17. DOI: https://doi.org/10.1002/berj.3570

Bernstein, B. (2000). Pedagogy, symbolic control and identity: Theory, research, critique. Oxford: Rowman \& Littlefield Publishers.

Bordieu, P. (1997). Outline of a theory of practice, transl. by Richard Nice. Cambridge: Cambridge University Press.

Cigman, R. (2012). We need to talk about well-being. Research Papers of Education, (27), 449-462.

Deng, Z. (2015). Michael Young, knowledge and curriculum: an international dialogue. Journal of Curriculum Studies, 723-732. DOI:10.1080/00220272.

Durkheim, E. (1956). Education and sociology. New York: Free Press.

EU. (2017, March 25). The Rome Declaration. Retrieved from European Council: https://www.consilium.europa.eu/en/press/press-releases/2017/03/25/rome-declaration/

EU. (2019). Council Recommendation on Key Competences for Lifelong Learning. Retrieved from https://ec.europa.eu/education/education-in-the-eu/council-recommendation-onkey-competences-for-lifelong-learning_en

Fadel, C., Bialik, M., \& Trilling, B. (2015). Four-Dimensional Education. Boston: Center for Curriculum Redesign. DOI:978-1518642562

Gericke, N., Hudson, B., Olin-Scheller, C., \& Stolare, M. (2018, November). Powerful knowledge, transformations and the need for empirical studies across school subjects. London Review of Education, 3(16.), 428-444. DOI:10.18546/LRE.16.3.06

Lambert, D. (2013, November 13). The science teacher, science thinking resources and pedagogy. Retrieved from https://www.youtube.com/watch? $v=r$ _S5Denaj-k\&t=53s

Lambert, D. (2018). The road to Future 3: the case of geography. In D. Guile, D. Lambert, \& M. Reiss (Eds.), Sociology, curriculum studies and professional knowledge: New perspectives on the work of Michael Young (pp. 132-145). London: Routledge.

Lennon, K. (2010, June 23). Re-enchanting the World: The Role of Imagination in Perception. Cambridge University Press, 3(85), 375-389. DOI: https://doi.org/10.1017/ S0031819110000239

Maude, A. (2015). What is Powerful knowledge and can it be found in the Australian geography curriculum? Geographical Education, 28.

Mcfahn, R. (2019, April 4). So what is 'Powerful knowledge?'.

Muller, J., \& Young, M. (2019, January). Knowledge, power and powerful knowledge revisited. The Curriculum Journal. DOI:10.1080/09585176.2019.1570292

Oganisjana, K. (2012). Uznēèējspēja un uznēmī̄ba. Riga: Raka. DOI:9789984462356

Playfair, E. (2015, August 19). What is powerful knowledge? Retrieved from https://eddieplayfair.com/2015/08/19/what-is-powerful-knowledge/

UNESCO. (2019). Futures of Education: learning to become. Retrieved from 
SOCIETY. INTEGRATION. EDUCATION

Proceedings of the International Scientific Conference. Volume III, May $22^{\text {th }}-23^{\text {th }}, 2020.134-142$

https://unesdoc.unesco.org/ark:/48223/pf0000370801?posInSet=444\&queryId=812a8f4 2-ff53-4977-ab6a-cd13641a499e

Weinert, F. (2001). Concept of competence: A conceptual clarification. In D. S. Rychen \& L. H. Salganik (Eds.), Defining and selecting key competencies (pp. 45-65). Hogrefe \& Huber Publishers.

Wheelahan, L. (2007). How competency-based training locks the working class out of powerful knowledge. British Journal of Sociology of Education, 28(5), 637-651. DOI:10.1080/01425690701505540

White, J. (2018). The weakness of powerful knowledge. London Review of Education, 16(2), 325-335. DOI:10.18546/LRE.16.2.11

White, J. (2019). The end of powerful knowledge? London Review of Education, 3(17), 429438. DOI:10.18546/LRE.17.3.15

Young, M. (2009). Education, globalization and the 'voice of knowledge'. Journal of Education and Work, 22, 193-204.

Young, M. (2013). Powerful knowledge: an analytically useful concept or just a 'sexy sounding term'? A response to John Beck's 'Powerful knowledge, esoteric knowledge, curriculum knowledge'. Cambridge Journal of Education, 43, 195-198.

Young, M. (2014, March 25). The curriculum and the entitlement to knowledge.

Young, M., \& Muller, J. (2013). On the powers of powerful knowledge. Review of Education, 229-250.

Young, M., \& Muller, J. (2016). Curriculum and specialization of knowledge. New York: Routledge. DOI:978-1-1138-81491-2

Young, M., Lambert, D., Roberts, D., \& Roberts, M. (2014). Knowledge and the Future School. London: Bloomsbury Academic. DOI:978-1-4725-3473-6 